\title{
VARIABILITY OF SUNFLOWER HEAD/CAPITULUM BY NEW MORPHOLOGICAL CHARACTERS
}

\author{
Nicolaie Ionescu $^{1 *}$, Mariana Nicolaie ${ }^{1}$, Oana Badea ${ }^{1}$, Diana Popescu ${ }^{1}$, Robert Gheorghe ${ }^{1}$, \\ Magdalena Podea $^{1}$, Cristina Ghiorghe ${ }^{1}$, Cătălin Dinuță ${ }^{1}$ \\ ${ }^{1}$ Agricultural Research and Development Station Piteşti, \\ Piteşti-Slatina road km. 5, 117030, Piteşti, România
}

\begin{abstract}
New studies on the morphological characteristics of sunflower plants could provide new systems and directions in the complex progress of the future improvement of hybrids. Through the complex (Encheva \& Shindrova, 2014) and wide genetic dowry together with the concrete cultivation conditions of the sunflower, the characteristic expression of the plant morphology takes place. In the recent improved Hysun 162 IT hybrid, some new characters were found, specific to the semi-early maturity group. Thus, the diameter of the sunflower head/capitulum had an average of $17 \mathrm{~cm}$. The weight of the sunflower head was $105 \mathrm{~g}$ together with the achenes produced and only $39 \mathrm{~g}$ empty head, without achenes. The average of number of achenes/ head was 1470, and their weight was $65 \mathrm{~g}$. The percentage of empty achenes was 2-3\%, and the mass of one thousand seeds was on average $44 \mathrm{~g}$. The seeds had a length of $10 \mathrm{~mm}$ and width of $5 \mathrm{~mm}$. Positive correlations were generally obtained between the morphological characters of the sunflower head. Though this study carried out on the components of the heads of this new sunflower hybrid, a good adaptability to the current zonal agriculture was found.
\end{abstract}

Keywords: achenes/seeds, head/ capitulum, sunflower, variability

\section{INTRODUCTION}

Sunflower- Helianthus annuus L. [pro syn. H. annuus L. var. macrocarpus (DC) Cockerell] is today one of the oil plants of great agricultural importance (Niknesham et al., 20110). The qualities of the plant found in various forms, have evolved spectacularly lately, especially for oil production. Thus, through successive stages of improvement, it was possible to increase the seed content in oil to over $50 \%$. From a food point of view, this oil has special qualities through: taste, smell, high nutritional and caloric value (Martin \& Farina, 2016), long storage. In fact, the whole plant has a value of fodder (head, seed husks), energy (stems) and honey (Atamian et al., 2016; Henzé et al., 2016; Henzé et al., 2018). The current cultivated form, with probable descent from the subspecies $H$. annuus lenticularis (Riesberg et al., 2004), is characterized by a single inflorescence (Jean, 1994), with a specific yellow-orange floral system and large seeds (Niering \& Olmstead, 1985). The sunflower has the diploid form of the chromosomal number, $2 n=14$. From a morphological point of view, namely at maturity, the head (or antode) usually has the shape of a concave disc, with a diameter of 5-40 cm. The achenes have length of $8-25 \mathrm{~mm}$, width of 4-13 mm, elongated-sharp shape and the color of the pericarp blackish with white stripes. Research conducted to observe the 
variation of some characters of sunflower capitulum in the cultivated form included: diameter and weight of the head with achenes, weight of the head without achenes, number of achenes/capitulum, weight of achenes/ capitulum, seeds percent of the capitulum, percentage of the empty seeds, mass of one thousand seeds (MTS), length and width of achenes.

\section{MATERIALS AND METHODS}

In tye last two years, the Hysun 162 IT sunflower hybrid has been cultivated in the semi-early precocity category. The experience in which the determinations were made had a technology for normal cultivation conditions, recommended by the resort. The block experimental design was used, with variants of $25 \mathrm{~m}^{2}$ in 4 repetitions. At full maturity, 25 plants were randomly selected from each repetition (a total of 100), the heads were cut and brought to the laboratory. The 100 capitulum were measured and determined: head diameter, head weight with grains, weight of head without grains, number of grains/ head, weight of seeds/ head, seeds percent of head, percentage of empty seeds, mass of one thousand of seeds (MTS), and seeds sizes: length and width.

The obtained morphological characters were analyzed by the method of histograms or frequency polygons. In their expression were used both the absolute values as such and as class intervals, established according to the specific string of values obtained. The study highlighted several aspects, namely: a) the modal values (higher frequencies), b) the limits of the variability intervals of the studied characters, and c) the specificity of each character of the sunflower bybrid in the analyzed area. The correlations were established between the analyzed characters, with the help of which their tendencies within the studied ecotype could be observed. Excel was used to express values. The significance of the correlation coefficients was obtained by comparing with the $r_{\max }$ values (Erna Weber, 1961) for the levels of 5\%, $1 \%$ and $0.1 \%$ of the transgression probabilities.

In the statistical calculation of all the values obtained, the analysis of variance (Anov test) was used, on the variation strings. Statistical parameters (Adam, 2003) were calculated using the formulas:

$\overline{\mathrm{a}}=\Sigma \mathrm{x} / \mathrm{n}$, where $\overline{\mathrm{a}}=$ the average of the determinations, and $\mathrm{x}=$ the determined values,

$\mathrm{s}^{2}($ variance $)=1 /(\mathrm{n}-1)\left[\Sigma \mathrm{x}^{2}-(\Sigma \mathrm{x})^{2} / \mathrm{n}\right]$,

$\mathrm{s}($ standard error $)=\sqrt{\mathrm{s} 2}$,

$\mathrm{s} \%($ variation coefficient $)=\mathrm{s} / \overline{\mathrm{a}} .100$.

\section{RESULTS AND DISCUSSIONS}

Variability of head/capitulum characters. The sunflower inflorescence matures, in the shape of a recurved disc in different degrees, being full of achenes/ seeds and parenchymal tissue, specifically. From the measurements it was found that the diameter of the head was between 13 and $22 \mathrm{~cm}$. The modal value (higher frequency values) was between 16 and $19 \mathrm{~cm}(16-17 \%)$. The heads with small diameters, of 13-14 cm constituted $4 \%$ each, and those of $22 \mathrm{~cm}$ only $1 \%$ (figure 1). The total weight of the heads had values between 70 and $150 \mathrm{~g}$. They dominated those between 90 and $130 \mathrm{~g}$ $(22-25 \%)$. Heads with small total weights of $70 \mathrm{~g}$ accounted for $10 \%$, while the heaviest accounted for only $1 \%$ of the total (figure 2 ).

After extracting the achenes, it was found that weights between 25 and $60 \mathrm{~g}$ were obtained for the empty head. Weights between 35 and $45 \mathrm{~g} /$ head dominated (figure 3). The cultivated Hysun 162 IT hybrid thus has the characteristic head that it forms (figure 4).

The number of achenes/ seeds in an head was generally between 1100 and 2000, thus proving the increased genetic possibilities in the formation of fruit in inflorescence. Of these, those with 1400 


\section{Current Trends in Natural Sciences}

Vol. 10, Issue 19, pp. 440-446, 2021

https://doi.org/10.47068/ctns.2021.v10i19.058

Current Trends in Natural Sciences (on-line)

achenes/ head (21\%) dominated, being followed by those with 1500-1700 achenes/ head (13-15\%) (figure 5). Heads with less than 1100 accounted for 4\%, while those with more than 2000 achenes accounted for only $1 \%$. The seeds weight/ head was between 40 and $110 \mathrm{~g}$. dominant were those between 50 and $70 \mathrm{~g}(18-22 \%)$. Heads with $40 \mathrm{~g}$ seeds constituted 5\%, and those with $100 \mathrm{~g}$ were only $3 \%$ from total (figure 6 ).

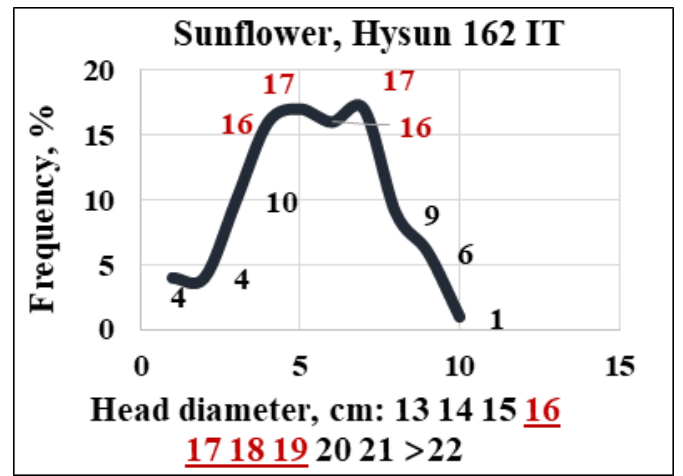

Fig. 1. Frequencies of head diameter

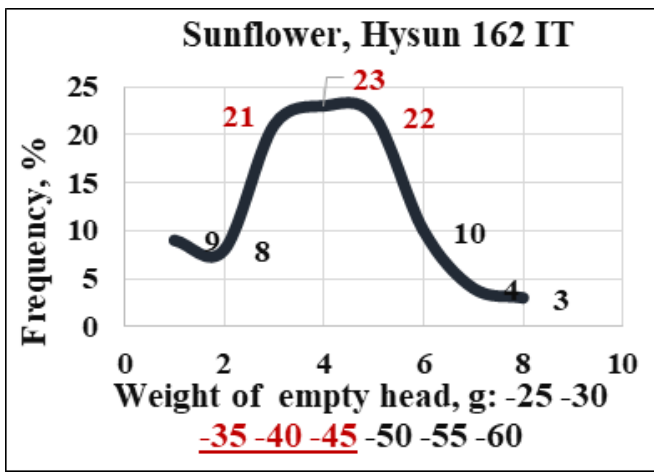

Fig. 3. Frequencies of empty head

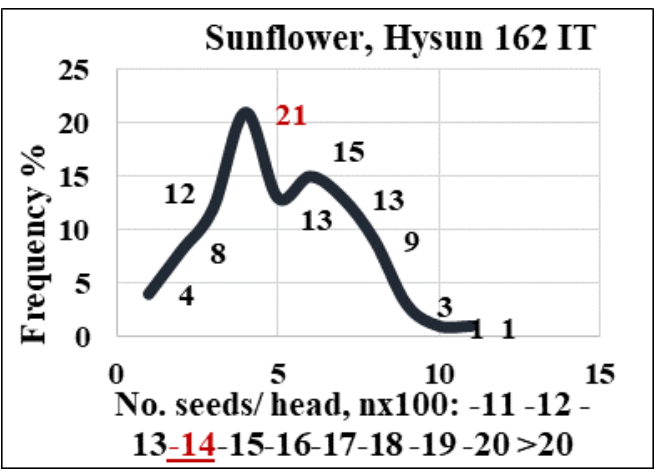

Fig. 5. Frequencies of no. seeds/head

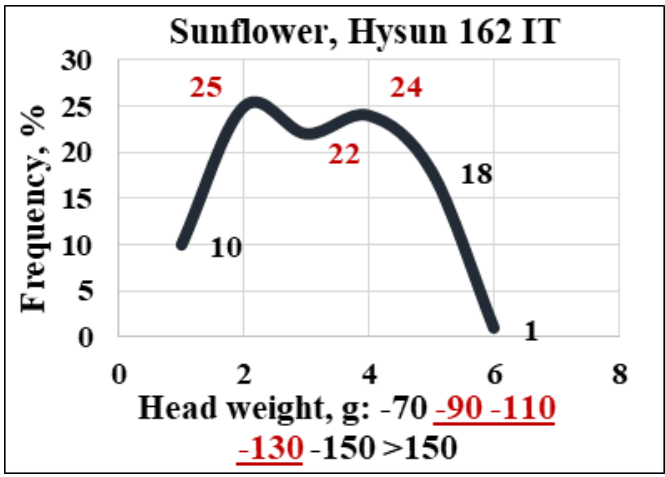

Fig. 2. Frequencies of head weight

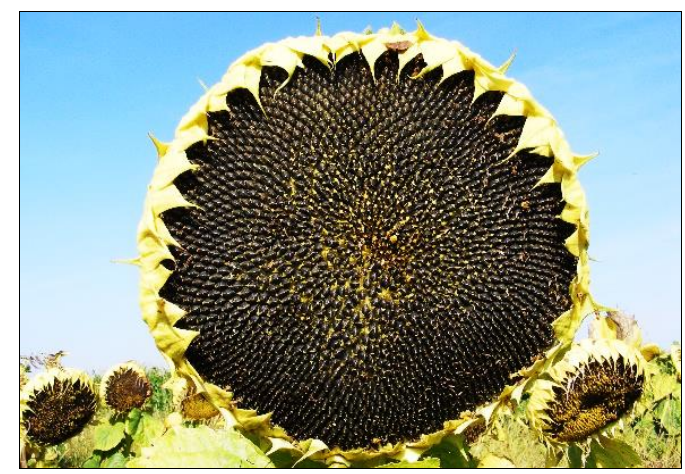

Fig. 4. Hysun 162 IT hybrid

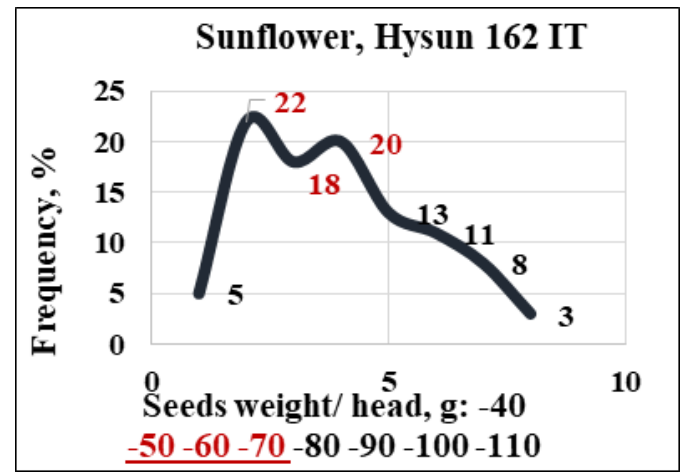

Fig. 6. Frequencies of seeds weight/head

The proportion of achenes in the head, as weight, experienced a variability between under $48 \%$ and over $75 \%$. Dominant were the heads whose fruits constituted between 59 and $67 \%(22-25 \%$ frequency), being followed by those with $71 \%$ (15\% frequency). Heads with lower percent in achenes constituted 1-2\% frequency, and those with higher percent, 1-4\% (figure 7). 


\section{Current Trends in Natural Sciences}

Vol. 10, Issue 19, pp. 440-446, 2021

https://doi.org/10.47068/ctns.2021.v10i19.058

Current Trends in Natural Sciences (on-line)

Empty seeds, without a core, grow in non-fertilizing conditions, but also in periods of drought. However, the genetic factor and bees continue to reduce the percentage of empty seeds in the head. The determinations carried out showed that this percentage of empty seeds was between 1 and over $8 \%$. The heads dominated with a percentage of $1 \%$ empty seeds $(44 \%)$, after which the proportions of these empty seeds in the head increased, but with lower and lower frequencies (figure 8). It is possible that the hybrid has demonstrated a slightly better adaptability to growing conditions, along with proper pollination.

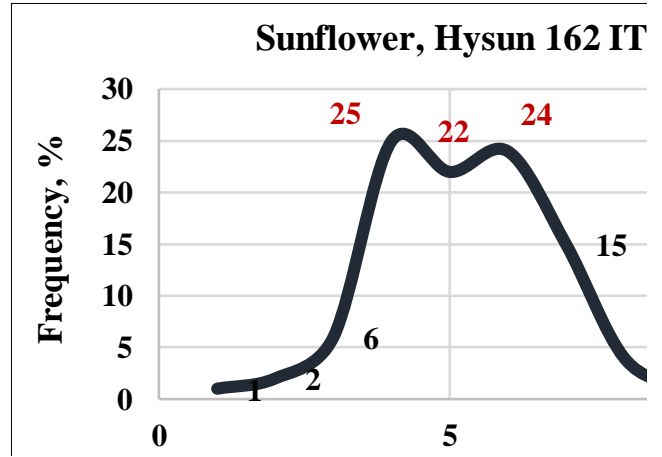

Fig. 7. Weights proportion of seeds/ head

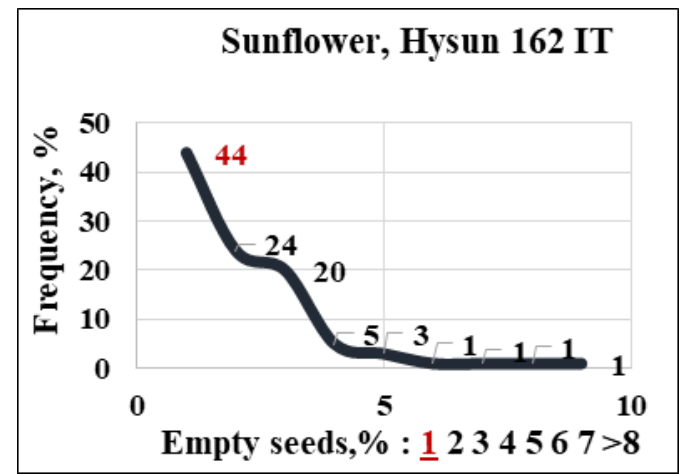

Fig. 8. Proportions of empty seeds/head

Variability of achene/ seeds characters. Achenes or sunflower seeds have evolved as the plant has improved the characteristics that favor the acumulationmof oil, with special nutritional value. The seed/ achene, by its morphology characterized the cultivated hybrid. The determinations showed variability of the achenes, both in length and thickness, but also in absolute mass.

Thus, the length of the achene of this hybrid was between 8 and $12 \mathrm{~mm}$. It dominated the length of $10 \mathrm{~mm}$ (53), followed by those with $9 \mathrm{~mm}(23 \%)$ and those with $11 \mathrm{~mm}(19 \%)$. The shorter achenes constituted $4 \%$, and the $12 \mathrm{~mm}$ ones, $1 \%$ (figure 9). The thickness of the achene was between 3 and $7 \mathrm{~mm}$. They dominated achenes with $5 \mathrm{~mm}$ thockness (51\%) (figure 10).

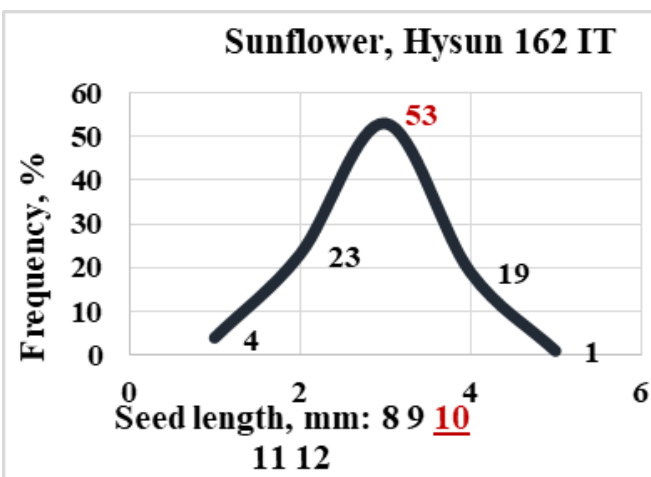

Fig. 9. Frequencies of achene length

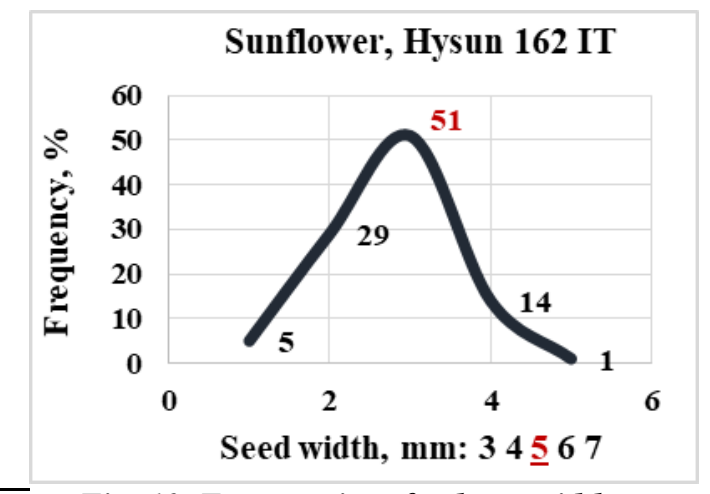

Fig. 10. Frequencies of achene width

The absolute mass of sunflower seeds is characteristic of each hybrid and depends to a large extent on the technology used. The determinations showed that this character was between 30 and over 65 $\mathrm{g}$. The seeds with (MTS) of $44 \mathrm{~g}(27 \%)$ dominated, being followed by those with values of $37 \mathrm{~g}$ 
(24\%), but also by those with $51 \mathrm{~g}(23 \%)$ (figure 11). From these data it is found that the hybrid formed smaller relative seeds (figure 12).

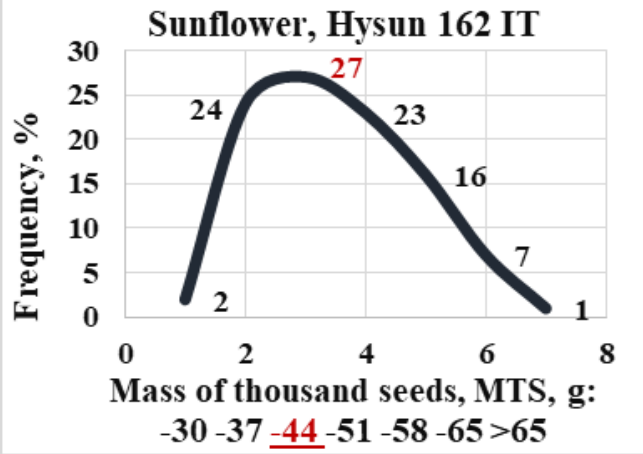

Fig. 11. Frequencies of MTS

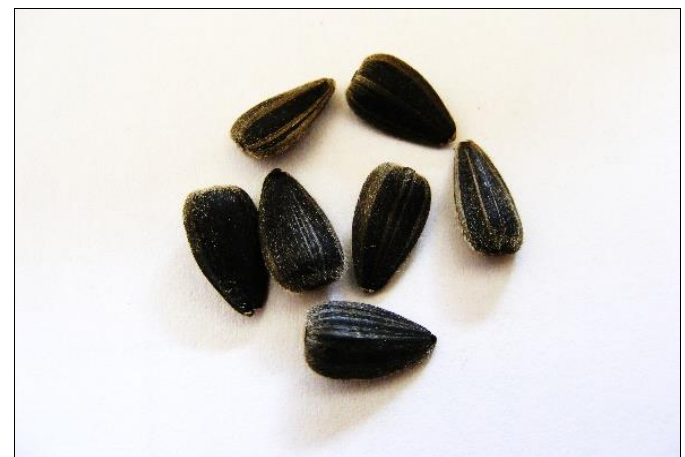

Fig. 12. The seeds of Hysun 162 IT hybrid

Correlations between morphological characters. Between the characters of the head of the analyzed hybrid, positive, favorable connections were found in most cases (table 1). Thus, the diameter of the head, the weight of the head and the mass of the empty head were significantly positively correlated with most of the other characters. Exceptions were the percentage of the empty seeds and the percentage of the seeds in the head. The percentage of empty seeds was significantly negatively correlated with MTS and with seed percentage/head. A negative connection was also obtained with the weight of the achenes on the head. The number of achenes/ head and their weight correlated very favorably with other characters, instead the number of achenes correlated positively but insignificantly with the size of the seeds. The mass of a thousand seeds- MTS was positively correlated with the dimensions of the achene, and a very close connection was established between the dimensions of the achene.

Table 1. Corelations betwee the main characters of sunflower Hysun 162 IT hybrid

\begin{tabular}{|c|c|c|c|c|c|c|c|c|c|c|}
\hline Indices & $\begin{array}{c}\varnothing \text { head } \\
\text { cm }\end{array}$ & $\begin{array}{c}\text { Head } \\
\text { weight, } \\
\mathrm{g}\end{array}$ & $\begin{array}{c}\text { Empty } \\
\text { head } \\
\text { weight, } g\end{array}$ & $\begin{array}{l}\text { \% empty } \\
\text { achenes }\end{array}$ & $\begin{array}{c}\text { No. } \\
\text { achene/ } \\
\text { head }\end{array}$ & $\begin{array}{l}\text { Achenes } \\
\text { weight, } g\end{array}$ & $\begin{array}{c}\text { Achene/ } \\
\text { head, } \\
\%\end{array}$ & $\begin{array}{c}\text { MTS, } \\
\text { g }\end{array}$ & $\begin{array}{c}\text { Achene } \\
\text { length, } \\
\text { mm }\end{array}$ & $\begin{array}{c}\text { Achene } \\
\text { width, } \\
\text { mm }\end{array}$ \\
\hline Achene width. mm & $.454 * * *$ & $.345 * * *$ & $.353 * * *$ & .101 & $.215 *$ & $.336 * * *$ & .080 & .331**** & $.493 * * *$ & 1 \\
\hline Achene length. mm & $.219 *$ & $.296 * *$ & $.279 * *$ & $.250 * *$ & $.298 * *$ & $.321 * * *$ & .100 & $.208 *$ & 1 & \\
\hline MTS, $\mathrm{g}$ & $.591 * * *$ & $.770 * * *$ & $.586 * * *$ & $-.200 *$ & $.251 * *$ & $.849 * * *$ & $.424 * * *$ & 1 & & \\
\hline Achenes/head,\% & -.001 & .063 & -.171 & $-.286^{* *}$ & .179 & $.423 * * *$ & 1 & & & \\
\hline Achene weight/chead, g & $.712 * * *$ & $.924 * * *$ & $.681 * * *$ & -.098 & $.717 * * *$ & 1 & & & & \\
\hline No. achene/head & $.566 * * *$ & $.703 * * *$ & $.517 * * *$ & .121 & 1 & & & & & \\
\hline \% empty achenes & .072 & .017 & .180 & 1 & & & & & & \\
\hline Empty head weight, $\mathrm{g}$ & $.786 * * *$ & $.816 * * *$ & 1 & & & & & & & \\
\hline Head weight, $\mathrm{g}$ & $.792 * * *$ & 1 & & & & & & & & \\
\hline Ø head, cm & 1 & & & & & & & & & \\
\hline \multicolumn{11}{|c|}{ LSD $5 \%=.19$} \\
\hline
\end{tabular}

Statistical analysis of the morphological characters variability. The results obtained in the morphological analysis of some sunflower characters showed specific aspects. Thus, the diameter of the head had an average value of $17.45 \mathrm{~cm}$. The wieght of the head with seeds was $105 \mathrm{~g}$, while the head without seeds weighted $38.5 \mathrm{~g}$. Empty seeds accounted for $2.2 \%$ (table 2). The number of seeds per head was 1470 , they weighted $65.3 \mathrm{~g}$ and represented $62 \%$ of the weight of the head. The mass of a thousand grains was on average $38.5 \mathrm{~g}$, the length of the seed was $9.9 \mathrm{~mm}$, and the thickness was only $4.75 \mathrm{~mm}$. There was little variability in seeds percent from one head and seed length the average variability had the diameter of the head, the number of seeds/ head and the 
thickness of the seed. Achenes/ head weight, empty seeds, seed weight/ head and MTS had high varaibility (table 3 ).

Table 2. Statistical indices of sunflower head characters, Hysun 162 IT hybrid

\begin{tabular}{|c|c|c|c|c|}
\hline \multirow{2}{*}{ Indices } & \multicolumn{4}{|c|}{ Capitulum/ head } \\
\cline { 2 - 5 } & $\begin{array}{c}\text { Diameter } \\
\text { cm }\end{array}$ & $\begin{array}{c}\text { Achene } \\
\text { weight, g }\end{array}$ & $\begin{array}{c}\text { No achene } \\
\text { weight, } \mathrm{g}\end{array}$ & $\begin{array}{c}\text { Empty seeds, } \\
\%\end{array}$ \\
\hline Mean, $\overline{\mathrm{a}}$ & $\mathbf{1 7 . 4 5}$ & $\mathbf{1 0 4 . 9 8}$ & $\mathbf{3 8 . 5 0}$ & $\mathbf{2 . 2 3}$ \\
Variance, s ${ }^{2}$ & 4.654 & 693.36 & 68.879 & 3.209 \\
Std. error, s & 2.157 & 26.332 & 8.299 & 1.791 \\
Var. coef., s\% & $\mathbf{1 2 . 3 6}$ & $\mathbf{2 5 . 0 8}$ & $\mathbf{2 1 . 5 6}$ & $\mathbf{8 0 . 3 3}$ \\
\hline
\end{tabular}

Table 3. Statistical indices of sunflower achene haracters, Hysun 162 IT hybrid

\begin{tabular}{|c|c|c|c|c|c|c|}
\hline \multirow{2}{*}{ Indices } & \multicolumn{6}{|c|}{ Achenes/ seeds } \\
\cline { 2 - 7 } & $\begin{array}{c}\text { Number/ } \\
\text { head }\end{array}$ & $\begin{array}{c}\text { Weight } \\
\mathrm{g}\end{array}$ & $\begin{array}{c}\text { Seeds/ } \\
\text { head, \% }\end{array}$ & $\begin{array}{c}\text { MTS, } \\
\mathrm{g}\end{array}$ & $\begin{array}{c}\text { Length, } \\
\text { mm }\end{array}$ & $\begin{array}{c}\text { Width, } \\
\mathrm{mm}\end{array}$ \\
\hline Mean $\overline{\mathrm{a}}$ & $\mathbf{1 4 7 0 . 1 4}$ & $\mathbf{6 5 . 3 1}$ & $\mathbf{6 1 . 9 7}$ & $\mathbf{3 8 . 5 0}$ & $\mathbf{9 . 9 0 4}$ & $\mathbf{4 . 7 4 9}$ \\
Variance s & 51.534 & 336.80 & 36.74 & 68.879 & 0.628 & 0.5786 \\
Std. error, s & 227.01 & 18.35 & 6.061 & 8.299 & 0.793 & 0.7589 \\
Var. coef., s\% & $\mathbf{1 5 . 0 0}$ & $\mathbf{2 8 . 1 0}$ & $\mathbf{9 . 7 8}$ & $\mathbf{2 1 . 5 6}$ & $\mathbf{8 . 0 1}$ & $\mathbf{1 5 . 9 8}$ \\
\hline
\end{tabular}

\section{CONCLUSIONS}

The morphological characteristics of the sunflower head, studied in a new hybrid, had the specific aspects. The choice of this hybrid was made due to recent genetic improvements, especially for its high productive potential.

The head measured an average of $17 \mathrm{~cm}$ and weighted $105 \mathrm{~g}$. By removing the seeds, the empty head was obtained, its weight was $38 \mathrm{~g}$. Empty seeds accounted for about $2 \%$ of the total. On an average head of sunflower, 1470 seeds were formed that weoghted $65.3 \mathrm{~g}$. Of the total weight of the head, the seeds constituted $62 \%$. Instead, the mass of a thousand seeds was $38.5 \mathrm{~g}$. An achene measured on average $9.9 \mathrm{~mm}$ long and $4.75 \mathrm{~mm}$ thick.

Simple correlations were established between all the studied characters, most of them positive and with very good statistical assurance. These very close positive links actually demonstrate the great productive possibilities that this Hysun 162 IT hybrid has.

Given the valuable morphological charactetistics it has expressed, we recommend for the farm culture this hybrid from the early precocity group.

\section{REFERENCES}

Adam, J. A. (2003). Mathematics in Nature: Modelling Patterns in the Natural World (1-392), Princeton University Press, New Jersey, USA. ISBN 978-0-691-11429-3.

Atamian, H. S., Creux, N. M., Brown, E. A., Garner, A. G., Blackman, B. K., Harmer, S.L. (2016). Circadian regulation of sunflower heliotropism, floral orientation, and pollinator visits. Science, 353 (6299), 587-590.

Encheva, J. C. M., and Shindrova, P. (2014). Developing Mutant Sunflower Line (Helianthus annuus L.) By Combined Used Of Classical Method with Induced Mutagenesis and Embryo Culture Method. Bulgarian Journal of Agricultural Science, 14(4), 397-404.

Heuzé V., Tran G., Hassoun P., Lessire M., Lebas F. (2016). Sunflower meal. Feedipedia, a programme by INRA, CIRAD, AFZ and FAO. https://www.feedipedia.org.

Heuzé V., Tran G., Hassoun P., Lessire M., Lebas F. (2018). Sunflower hulls and sunflower screenings. Feedipedia, a programme by INRA, CIRAD, AFZ and FAO. https://www.feedipedia.org.

Jean, R. V. (1994). Fibonacci packing efficiency, Phyllotaxis, 185. 


\section{Current Trends in Natural Sciences}

Vol. 10, Issue 19, pp. 440-446, 2021

https://doi.org/10.47068/ctns.2021.v10i19.058

Current Trends in Natural Sciences (on-line)

ISSN: 2284-953X

Current Trends in Natural Sciences (CD-Rom)

ISSN: 2284-9521

ISSN-L: 2284-9521

ISSN-L: 2284-9521

Martin, C.S., Farina, W.M. (2016). Honeybee floral constancy and pollination efficiency in sunflower (Helianthus annuus) crops for hybrid seed production. Apidologie. 47 (2), 161-170.

Niering, W. A., Olmstead, N.C. (1985). The Audubon Society Field Guide to North American Wildflowers, Eastern Region. Knopf, 384. ISBN 0-394-50432-1.

Nikneshan, P., Karimmojeni, P., Moghanibashi, M., Hosseini, N. (2011). Allelopathic potential of sunflower on weed management in safflower and wheat. Australian Journal of Crop Science. 5(11), 1434-40. ISSN 1835-2707.

Rieseberg, L.H., Hartner A.V., Gardner K.A., Falush D., Lentz D.L., Bye R.A. (2004). Origin of Extant Domesticated Sunflowers in Eastern North America. Nature, 430, 201-205. 